\title{
Scientific note: cavity-nesting Osmia bruneri bees (Megachilidae) can use fruit pulp for nest construction
}

\author{
James H. CANE
}

USDA-ARS Pollinating Insect Research Unit, Utah State University, Logan, UT 84322-5310, USA

Received 7 August 2018 - Revised 27 November 2018 - Accepted 28 January 2019

\begin{abstract}
The cavity-nesting solitary bee Osmia bruneri (Hymenoptera: Megachilidae) normally partitions and plugs its nest tunnel with masticated leaf pulp. In 2018, many females of a captive population were observed collecting pulp from drupelets of both unripe and ripe red raspberries (Rubus idaeus) despite available foliage from this plant as well as five weedy forbs. Females capped 122 nests with raspberry pulp, the material that they used for their nests' cell partitions as well. Such red nest plugs were never produced by the preceding ten captive generations of this bee (about 3000 nests), even when caged with raspberries. Raspberry fruit pulp proved to be of intermediate preference for nest construction among alternative foliar choices offered to nesting females.
\end{abstract}

\section{Apiformes / Megachilidae / nesting / Osmia bruneri / Rubus idaeus}

Bees of the large holarctic genus Osmia (Megachilidae) nest in various substrates, such as soil, beetle holes in deadwood, or plant stems. Females of a given Osmia species partition and plug their cylindrical nest tunnels with either mud or masticated leaf tissue (pulp or "mastic") (reviewed in Cane et al. 2007). A female transports it back to her nest as a molded ball tucked behind her mandibles (Neff and Simpson 1992; Torchio 1989). Nesting biologies of several manageable species of Osmia (Osmia) have been intensively studied for pollination of fruit trees; unlike most Osmia, these species use mud for nest construction (Torchio 1989; Maeta 1978; Bosch 1994). Much less is known about the nesting habits of most other Osmia species, leaving open the possibility of surprising discoveries, such as one species nesting in dried cow dung (Cane 2012). Here I report observing numerous females of a large captive population of the common western U.S. bee, Osmia bruneri Ckll., collecting and using fruit pulp as a novel plug and partition material for their nests.

Electronic supplementary material The online version of this article (https://doi.org/10.1007/s13592-019-00634-7) contains supplementary material, which is available to authorized users.

Corresponding author: J. Cane,

jim.cane2@gmail.com

Manuscript editor: Peter Rosenkranz
Like many other Osmia species, O. bruneri is univoltine, solitary, and polylectic. Females massprovision linear nests in pre-existing cavities and sometimes crevices which they typically partition and close with masticated leaf pulp (Frohlich 1983). For this study, a captive population of $\sim 500 \mathrm{O}$. bruneri was used that has been fostered and sometimes augmented for $>10$ annual generations for use in pollination trials both with raspberries (Rubus) (Andrikopoulos and Cane 2018) and an endangered locoweed, Astragalus packerdiae (Cane and McGinnis, unpubl. ). This population has multiplied well using various provided floral hosts, including Phacelia tanacetifolia (Hydrophyllaceae), Rubus idaeus (Rosaceae), and Astragalus filipes and Melilotus officinalis (Fabaceae). These bees readily nest in both drilled wooden nesting blocks (Frohlich 1983) and molded polystyrene blocks fitted with paper straw liners. Females of the preceding generations have always and only used masticated leaf pulp to partition and close their nests.

In 2018 , a large screenhouse $(16 \times 10 \times 4 \mathrm{~m})$ was seeded with $P$. tanacetifolia for pollen and nectar forage for $O$. bruneri. Wintered bees were released at a small nesting shelter (Cane 2006) provided with wooden and polystyrene nesting blocks. The nesting season became particularly hot and dry $\left(32-35{ }^{\circ} \mathrm{C}, 5-20 \%\right.$ relative humidity, $1000 \mathrm{w} / \mathrm{m}^{2}$ solar radiation). Amid the rows grew scattered weeds of Amaranthus, Convolvulus, Lactuca, Melilotus, and Portulaca, all potential leaf 
pulp species, plus a single remnant raspberry plant $(R$. idaeus ) (two 1-m canes) from a previous year's pollination experiments.

In early July, nests sealed with plugs of red pulp were noticed after the first week of nesting activity (Figure 1c). No screenhouse plants had red leaves. Only a few females were seen struggling to pulp leaves of the lone raspberry plant. Instead, bees were seen landing on its fruits. These females were biting at the drupelets that constitute raspberry fruits (Figure 1a). Females chewed the juicy pulp from around the individual seeds to mold colorful balls of masticated fruit pulp to carry back to their nests. Fruits used for pulping gained a unique appearance, as the bare, exposed seeds remained in place on the pale receptacle (Figure 1a). In one survey, 52 fruits bearing multiple exposed seeds were found. Some fruits had all their pulp removed, whereas others remained intact.
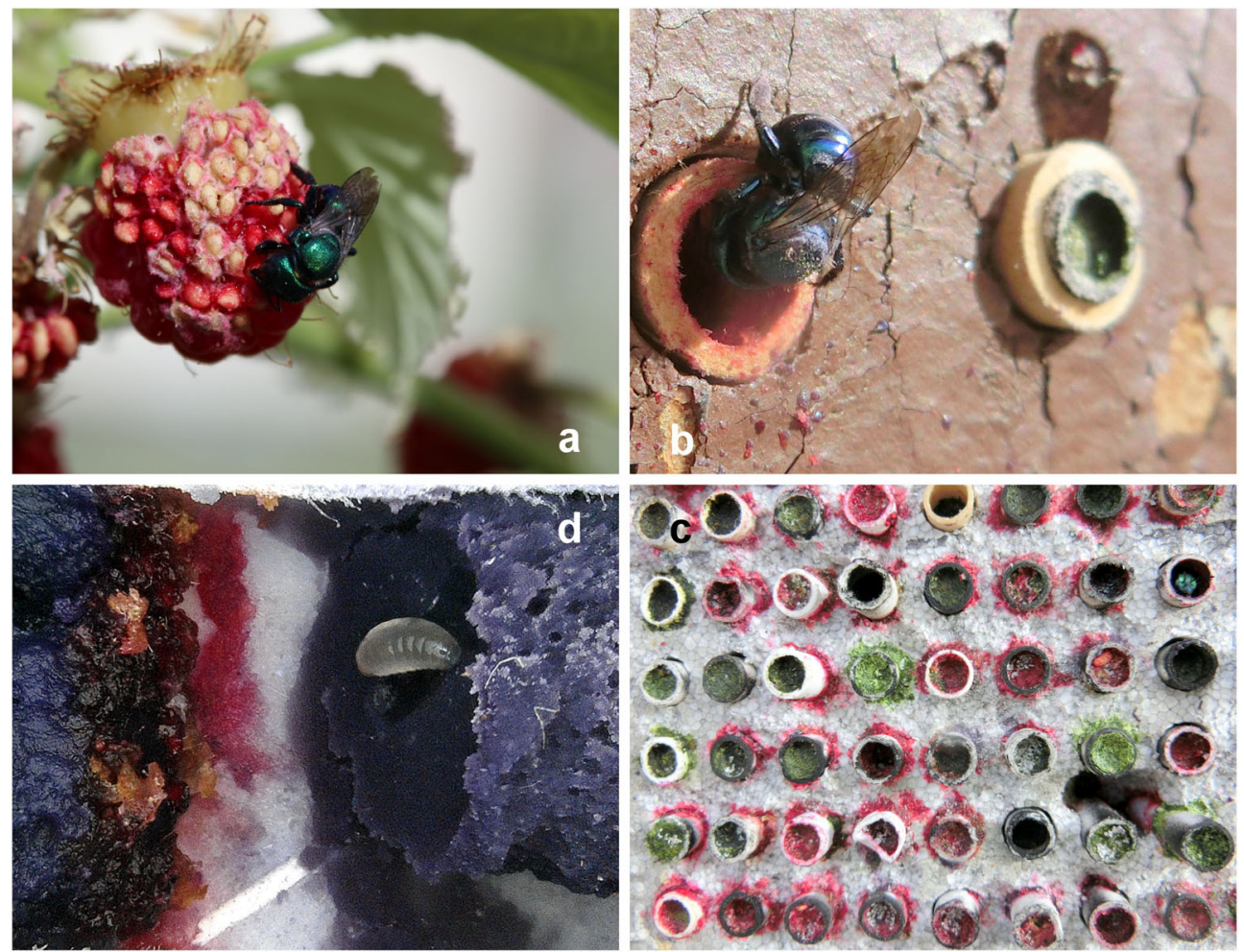

Figure 1. Use of $R$. idaeus fruit pulp or leaf mastic for nest construction by female $O$. bruneri bees. a Female removing pulp from a ripe fruit. Note exposed seeds left after pulp had been removed. b Female applying the red fruit pulp to her nest closure. $\mathbf{c}$ Mix of nest closures and seals made of either green leaf mastic or red fruit pulp. d Nest cell partition made of fruit pulp dividing two nest cells stocked with purple pollen provisions of $P$. tanacetifolia. 
vases of fresh stems bearing intact leaves. The glabrous, tender, and sparsely veined leaves of redbud (Cercis canadensis, Fabaceae) were first tried, as Megachile bees commonly cut them for pieces to line their nests (Eigenbrode et al. 1999), but after 24 h, no O. bruneri had chewed them. In contrast, when offered tender glabrous leaves of an unrelated species recommended by Frohlich (1983), Oenothera elata (Onagraceae), females began chewing these leaves as the vase was set down. In previous years, unconfined females of $O$. bruneri and $O$. sanrafaelae had also been seen pulping leaves of Sphaeralcea ambigua and the weed Malva neglecta (both Malvaceae) in the research garden, their use confirmed by seeing the characteristic stellate leaf hairs in nest partitions and plugs. When offered to screenhouse bees, females quickly discovered and began masticating them, as many as three females on one leaf. Females continued to pulp the wilting leaves, and by the next day, only a few leaf ribs remained. In contrast, nesting females ignored the mostly glabrous leaves of two other Malvaceae, Hibiscus syriacus and Callirhoe involucrata. Clearly, female O. bruneri have strong pulping preferences among leaf species for reasons that are neither predicted by taxonomy nor gross leaf characteristics. In this spectrum of pulp preferences, Rubus fruit seems intermediate.

The ready use of raspberry fruit pulp by nesting female $O$. bruneri to partition and plug their nest tunnels demonstrates broad versatility in their nesting behavior. The choice was not the aberrant behavior of a few individuals, because for a week or more, half of the nesting population used this source of pulp to cap their nests (as well as to partition the 5-9 cell nests comprising each nest). Would wild Osmia ever resort to fruit pulp for nest construction, and how would we know? Undoubtedly, females' use of raspberry fruit pulp in the screenhouse reflected limited foliar options. Their ready theft of pulp from neighbors' nests underscored the lack of good foliar options. Particularly, hot dry weather might have favored a juicier raspberry fruit pulp, as it remained workable even as it dried and also is sticky owing to sugary juices (akin to culinary fruit leathers). The distinctive exposed seeds of raspberries left after pulping by bees were readily noticed, but in the open, these might simply evidence feeding damage by herbivorous insects (e.g., grasshoppers). Lastly, the crimson nest closures made from raspberry pulp were brightly visible, but fruit pulps of other colors would not be showy. Hence, any use of fruit pulps by Osmia nesting in the wild would likely go unnoticed.
Interestingly, fruit pulp represents the first edible nest partition made by a solitary bee. Their mature larvae did not consume it, although nest scavengers (e.g., dermestid beetles) probably would. Of practical concern, both $O$. bruneri and $O$. aglaia are effective, manageable pollinators of raspberries grown in confinement (e.g., commercial high tunnels) (Andrikopoulos and Cane 2018; Cane 2005). To prevent later frugivory by these Osmia pollinators in confinement, growers should simply provide a preferred leaf pulp species for the bees' nest construction.

\section{ACKNOWLEDGMENTS}

Byron Love first noticed the red closures and provided some observations. Vince Tepedino provided helpful insights.

Note scientifique: Les abeilles Osmia bruneri (Megachilidae) qui nichent dans des cavités peuvent utiliser de la pulpe de fruit pour la construction d'un nid

\section{Apiformes / Megachilidae / nidification / Osmia bruneri / Rubus idaeus}

Wissenschaftliche Notiz: Höhlennistende Osmia bruneri Bienen (Megachilidae) können Fruchtfleisch für den Nestbau nutzen

\section{Apiformes / Megachilidae / Nistverhalten / Osmia bruneri / Rubus idaeus}

Publisher's note Springer Nature remains neutral with regard to jurisdictional claims in published maps and institutional affiliations.

\section{REFERENCES}

Andrikopoulos C., Cane J.H. (2018) Comparative pollination efficacies of five bee species on raspberry. J Econ Entomol. In press.

Bosch J. (1994) The nesting behaviour of the mason bee Osmia cornuta (Latr) with special reference to its pollinating potential (Hymenoptera, Megachilidae). Apidologie 25, 84-93.

Cane J.H. (2005) Pollination potential of the bee Osmia aglaia for cultivated red raspberries and blackberries (Rubus : Rosaceae). HortSci. 40, 1705-1708. 
Cane J.H. (2006) The Logan BeeMail shelter: A practical, portable unit for managing cavity-nesting agricultural pollinators. Amer Bee J. 146, 611-613.

Cane J.H. (2012) Dung pat nesting by the solitary bee, Osmia (Acanthosmioides) integra (Megachilidae: Apiformes). J Kansas Entomol Soc. 85, 262-264.

Cane J.H., Griswold T., Parker F.D. (2007) Substrates and materials used for nesting by North American Osmia bees. Ann Entomol Soc Amer. 100, 350-358.

Eigenbrode S.D., White M., Tipton J.L. (1999) Differential cutting by leaf-cutter bees (Megachilidae : Hymenoptera) on leaves of redbud (Cercis canadensis) and Mexican redbuds (Cercis canadensis var. mexicana) with different surface waxes. J Kansas Entomol Soc. 72, 73-81.
Frohlich D.R. (1983) On the nesting biology of Osmia (Chenosmia) bruneri (Hymenoptera: Megachilidae). J Kansas Entomol Soc. 56, 123-130.

Maeta Y. (1978) Comparative studies on the biology of the bees of the genus Osmia of Japan, with special reference to their managements for pollinations of crops (Hymenoptera: Megachilidae). Bull Tohoku Natl Agric Exper Sta. 57, 195209.

Neff J.L., Simpson B.B. (1992) Nest biology of Osmia (Diceratosmia) subfasciata Cresson in central Texas (Hymenoptera: Megachilidae). Pan-Pacific Entomol. 68, 15-26.

Torchio P.F. (1989) In-nest biologies and development of immature stages of three Osmia species (Hymenoptera: Megachilidae). Ann Entomol Soc Amer. 82, 599-615. 